\title{
5. Ministerial Accountability to Parliament
}

\author{
Phil Larkin
}

\section{Introduction: The decline of parliament?}

For many commentators, parliament's role in holding governments to account is the subject of laments for a better past and a central element in claims of a decline of parliament and of a democratic deficit (for a recent review, see the discussion in Flinders and Kelso 2011). The claim that parliament's role has been undermined has a number of dimensions. The primary one centres on the rise of organised and disciplined parties. In the parliamentary 'golden age' of the nineteenth century, with little in the way of disciplined parties, the executive could only maintain parliament's confidence by being constantly accountable to the legislature's wishes. With the emergence of organised parties, however, the executive effectively gained control over the legislature: the party leadership was able to use its control of promotion from the backbenches to ministerial positions or to committee chairs to enforce discipline on its members and, commanding a majority of members of the lower chamber, parliamentary government became a byword for executive dominance of the legislature, with parliamentarians reduced to 'lobby fodder' and executive accountability achieved only through the ballot box at election time. Flinders and Kelso (2011) note that by the early decades of the twentieth century the decline narrative had become dominant. It still — an academic backlash notwithstanding - holds considerable sway in the popular imagination: the Power report was an exemplar of the tradition, concluding that the Executive in Britain is now more powerful in relation to parliament than it has been probably since the time of Walpole' (Power Inquiry 2006, 128). It is, of course, important to note that the decline-of-parliament thesis relates only to some functions; parliament's role in, for instance, forming the executive has not declined in any way. But it is claimed that its role in forming governments has damaged its role in subsequently holding them to account; in Wheare's terms, its role in 'making the government' overshadows and compromises its role in 'making the government behave' (1963).

Of course, it should be noted that the decline-of-parliament thesis was primarily developed in the context of the United Kingdom (though see, for example, Elgie and Stapleton 2006 on Ireland; and the discussion relating to Australia in Halligan et al. 2007, 2-4). In Australia, where political parties' discipline in 
Parliament is pronounced, even by high, Westminster standards, a case could be made that its Parliament would have declined more than any other were it not for an unusually powerful second chamber composed via a voting system that ensures that it is usually outside government control. The roles of 'making the government' and 'making the government behave' have been divided between the two chambers of the Australian Parliament, whereas in the United Kingdom they remain, to a large degree, merged, with the House of Commons taking on both the government-formation role and the main scrutiny and accountability functions as well.

But the claim that the rise of the party has caused a decline of parliament has been supplemented by more recent developments. The mass media's focus on leadership and the resulting 'presidentialisation' of politics reinforce the role of the executive at the expense of parliament. The increased volume of legislation and its increased specialisation have seen the key nexus of policy making shift from the executive and parliament to the executive and the bureaucracy and even, if one accepts the claims of the network governance theorists, to a variety of key sectoral groups (Rhodes 1996). And then there is the tendency to outsource policy delivery to providers in the private sector, with accountability no longer a matter of hierarchical relationships but of horizontal, contractual ones (Bovens 2005, 199). Parliament, it is claimed, remains ill equipped to cope. The associated 'agencification' of government, with important policy work devised and implemented by public bodies at arm's length from government and outside direct ministerial control, has contributed to the feeling of the diminished importance of traditional, hierarchical accountability relationships. And the nation-state is now only one level at which 'governance' happens and policy is determined. The extent to which there has been an emergence of 'global governance' might be debated, as well as its impact on the sovereignty of national governments (has sovereignty been diminished?). Yet what cannot be disputed is that parliaments are firmly tied to the national level, leading to fears that key decisions have somehow escaped them.

The claims of the decline-of-parliament thesis have, of course, been strongly denied (see Cowley 2002; Flinders and Kelso 2011). What is true though is that there has been a rise to prominence of a variety of other organisations focused on accountability such as auditors-general, ombudsmen and various watchdogs and inspectorates. These bodies exist outside the traditional, hierarchical model of accountability running through the minister to parliament (Bovens labels them 'diagonal'; 2005, 196). Furthermore, they generally have at their disposal greater resources and specialist expertise with which to scrutinise government than has parliament.

It would be easy to conclude, under such circumstances, that parliament is ill equipped to perform its traditional role of holding the executive to account 
or that it is something of an irrelevance, undermined by its role in forming governments. Yet it remains the central plank of the government accountability framework for a number of reasons. First, from a legitimacy perspective, parliament is the only accountability institution directly elected by the citizenry and directly accountable to it through the ballot box. In a principal-agent formulation, parliamentary democracy sees the citizenry delegate its law-making powers to their parliamentarians who, in turn, delegate that power to a subset of their number who form the government in a 'chain of delegation' (Strøm 2003). In return, there is a chain of accountability running from agent to principal in the opposite direction: from government, through the rest of parliament, to the citizenry - the ultimate principals. It is for legitimacy reasons that at least some of the extra-parliamentary accountability sector works through parliament to some extent: the Australian National Audit Office (ANAO), for example, provides advisory support for the senate estimates process and the Joint Committee of Public Accounts and Audit (JCPAA), parliament's primary public accounts committee. Whilst not directly part of the hierarchical accountability relationship, its primary role has often been to better inform parliament.

Furthermore, accountability is not a single act and ministerial accountability to parliament has a number of dimensions. First, parliament has to have some means by which it can establish what decisions have been taken and with what effect. Second, it needs a means to extract from the minister some form of explanation (or 'account') of why decisions were taken and the effects of the outcomes while judgment is made about the adequacy of such explanations. And third, in the light of these, is the potential to impose some form of sanction or retribution: to be accountable, "[a]gents must not only be "called" to account but also be "held" to "account"' (Mulgan 2003, 9; see also Bovens 2005, 184-6). This accountability industry is generally limited in its capacity to sanction. If ministers have broken laws then they may be held to account and punished by the courts but, for the most part, ministerial performance is not primarily a matter of adherence to the laws of the land but of judgments (considered or otherwise) about governing competence. There is little scope for these unelected scrutineers of government to do more than make recommendations. If ministers are agents, it is ultimately to parliament as the principal that the task of sanctioning falls.

It should also be noted that the concept of 'accountability to parliament' is, in practice, a slight misnomer. Certainly, executive authority is derived from parliament and ministers remain answerable to it. But it suggests that parliament acts as a single, unified actor whereas in reality it is a forum in which ministerial accountability takes place (or is actively evaded). As King (1976) notes in relation to the British House of Commons, there is a series of relationships within parliament that determines the relative strength of the legislature vis-avis the executive and affects the capacity of parliament to hold government to 
account. The key relationships are between the government and the opposition, between the government and its own backbench, and between the government and the backbenches as a whole. As we shall see, these relationships impact upon different aspects of the accountability process. Moreover, the Australian Parliament comprises two chambers that usually have significantly different party compositions; those parties have different stakes in the accountability process. In this respect, opposition and minor parties carry out most of the heavy lifting of ministerial accountability. As the government-in-waiting, the opposition has a clear interest in highlighting poor performance and focusing on apparent misjudgments or evidence of maladministration. The party of government, on the other hand, will have a clear incentive to rebut accusations of poor performance, avoid its discovery or, where this is not possible, apportion blame elsewhere. They are also likely to have an incentive to minimise the opportunities through which they can be held to account (though this might be tempered by the knowledge that, once in opposition, the roles will change and their interest will be in maximising the capacity for executive scrutiny).

This picture of ministerial accountability to parliament is, then, highly politically charged and subjective; surely it must be possible to establish in a more objective fashion the extent of ministerial competence? Certainly governments have sought to put accountability on a less fluid and contingent footing. Ministerial codes have been devised that specify what it is that ministers should be accountable for, particularly in relation to the actions of the bureaucrats in their department (Special Minister of State 2008). Whilst the opposition might call for the resignation of the minister when a public servant in their department has made some costly error or misjudgment, the code states that the issue is whether the minister could reasonably have known about this or, once becoming aware of it, did not take adequate steps to remedy the situation. Instead of a purely rhetorical activity, blame apportionment becomes to some extent grounded by the standards set out in the code. There have also been attempts to change the focus of ministerial accountability to parliament away from inputs and process towards outputs (Mulgan 2008, 457-60).

Nevertheless, ministerial competence is not something that can be objectively defined according to common standards over which there is universal agreement. Policy rarely fails unambiguously and beyond dispute, and even in the case of the most apparently egregious errors of policy design and implementation, the label of ministerial incompetence, like that of policy 'failure' or 'fiasco', is contingent. When a policy fails, that failure will need to be discovered; it will be subject to explanation, which will attempt to show how there really has not been a failure at all or that the carefully designed policy has been undermined by a change in circumstances that could not possibly have been foreseen; and counterarguments that the results are worse than could have been expected or 
that changed circumstances should have been foreseen, or even that the policy was wrong-headed and should not have been introduced at all. For the minister responsible to be held to account (rather than simply called to account), the case for the prosecution will have to be seen publicly to have prevailed and the 'failure' label made to stick. Inevitably, ministerial competence is the product of the political process and will be defined by it.

In the principal-agent formulation, the delegation of decision making by the principal comes with the risk of agency loss: the possibility that the interests of the principal and agent diverge and the agent acts according to their own interests rather than those of their principal. In the context of parliaments, there are ex ante and ex post means of minimising agency loss. Ex ante means might include the selection of candidates for ministerial posts or the requirement that policy is approved by the parliamentary party, the wider party membership or by parliament itself. Alternatively, the principal may monitor the actions of their agent and require them to report back ex post.

\section{Questions With and Without Notice}

The best-known, most public and most infamous example of ex post monitoring is Question Time in the House of Representatives, when 'Questions Without Notice' are put to government members in the House. It is undoubtedly the most high-profile aspect of the parliamentary sitting period and attracts much media attention. This media attention has meant that its usefulness as a means of obtaining information has been overshadowed by its role as a setpiece confrontation between the government and the opposition: broadcast live and with all the lobby correspondents looking for stories, it becomes less an exercise in information gathering and more an opportunity for partisan point-scoring and a forum where leadership credentials are tested. Question Time ordinarily takes place every sitting day for a minimum of 45 minutes and usually for more than an hour. This is only a convention, however, and the prime minister can curtail it, choosing to take questions 'on notice' instead (Harris et al. 2005, 529). It ordinarily opens with the leader of the opposition asking a question of the prime minister, followed by a government backbencher, with the parties then alternating in this manner; on average, 18 questions are asked (Harris et al. 2005, 530). Question Time's historical roots in Westminster in the pre-mass-democracy era are evident, maintaining as it does that the central divide in parliament is between the government and the backbenches rather than between the government and opposition (hence the equal prominence accorded to government and non-government backbenchers). The high public and media profiles of Question Time ensure that questions from the opposition are primarily designed to embarrass the government, while those from the 
government backbenches are generally designed to publicise its achievements and to present it in the best possible light. Many of the questions from the government side are planned (the infamous 'Dorothy Dixer' tactic).

With Question Time in the House of Representatives so readily dismissed as party political theatre, it has attracted limited systematic study. Rasiah (2006) conducted an analysis of a sample of Questions Without Notice on the subject of Australia's military involvement in Iraq. She found it lacking as an accountability mechanism, with Dorothy Dixers predominant amongst questions from the government backbenches (and long-winded answers to them using up the allotted time) and ministers evading questions from the opposition. In a similar vein, whilst maintaining that even a Dorothy Dixer could be useful in accountability terms as it provides the minister to whom it is directed the opportunity to explain their position, McGowan (2008) regards Question Time as significantly less effective than the equivalent process in the United Kingdom, Canada or New Zealand. He analysed a sample of questions and answers from each parliament, concluding that relatively fewer questions are asked in the Australian House of Representatives than in other parliaments, and, of those asked by opposition MPs, fewer than half are likely to be given a proper or even partial answer (McGowan 2008, 75). Both studies were limited in scope, but nonetheless support the widely held view that Questions Without Notice are a largely ineffective means of ministerial accountability. One experienced parliamentarian concluded that 'question time is essentially an electioneering exercise, and is not usually a source of factual information. Indeed, new opposition members are warned never to ask a question without knowing the answer, for an unexpected answer might be very embarrassing' (Hamer 2004, 237-8).

Of course, extracting information from ministers is only one element of their accountability to Parliament. Extracting an explanation is also significant and Question Time could be said to fulfil this function. But given that answers can diverge significantly from the question, the duration is limited and members' questions offer only a 'single shot' with no opportunity to follow up, its usefulness in this respect is also limited. In terms of blame apportionment and the public testing of ministerial explanation, however, Question Time may play a role. If a minister appears to be too blatantly evading questions on a topic on an ongoing basis, there is the possibility that their credibility will be damaged, given the public nature of the occasion. In this sense, the media attention becomes a key component of accountability rather than a factor undermining it.

There are several modest reforms that seem to have the potential to redress the balance between 'making the government' and 'making the government behave'. The introduction of tighter rules on what constitute questions and answers would be a first step. Allowing the questioner to follow up with a 
supplementary question after the answer from the minister would simply bring Australian Question Time in line with many other comparable parliaments. A properly independent speaker would enforce these rules. In 1996, amidst promises of more independence, the Speaker did allow supplementary questions, providing they were from the member who had asked the original question and arose directly from the minister's answer. It was a short-lived experiment that irritated the Prime Minister sufficiently for the Speaker to be forced to resign from office.

If the furore surrounding Question Time limits its use as a means of extracting information from ministers, written 'Questions On Notice', where questions are tabled and answers given publicly but away from intense media scrutiny, would seem to have greater potential as a way of scrutinising government. There are, however, a number of factors that limit the usefulness of written questions in the accountability process. First, and most significantly, a minister is under no obligation to answer a question. Whilst this is the case for Questions Without Notice as well, the relative obscurity of written questions, buried in the Notice Paper, away from media and public attention, means that ministerial refusal to provide an answer to a question is unlikely to attract much publicity. Figure 5.1 shows how the numbers of both Questions On and Without Notice vary widely from year to year. And the number of Questions On Notice receiving an answer varies. For example, in the 2005-06 session, some 60 per cent of Questions On Notice received an answer. In the 2007-08 session (an election year), only 41 per cent of written questions were answered. But in 2009-10, the figure was 78 per cent (albeit of a smaller total). Refusal to answer may be justified on the grounds of the cost of providing an answer; however, this does not have to be demonstrated, providing a convenient way for ministers to avoid publicly giving information. And the time taken to produce an answer can be considerable - 90 days or more - which has the effect of reducing the relevance of the question and the information provided (if it is answered). There is also the limitation, inherent in the non-discursive format of written questions, of their scope. They can form a useful tool for a parliamentarian to extract specific bits of information on an issue that they are actively investigating. They are less useful in trying to explore an issue more broadly or as part of a 'fishing trip' to establish whether an issue is worth investigating further. This is a constraint not faced by, for instance, committee investigations. 


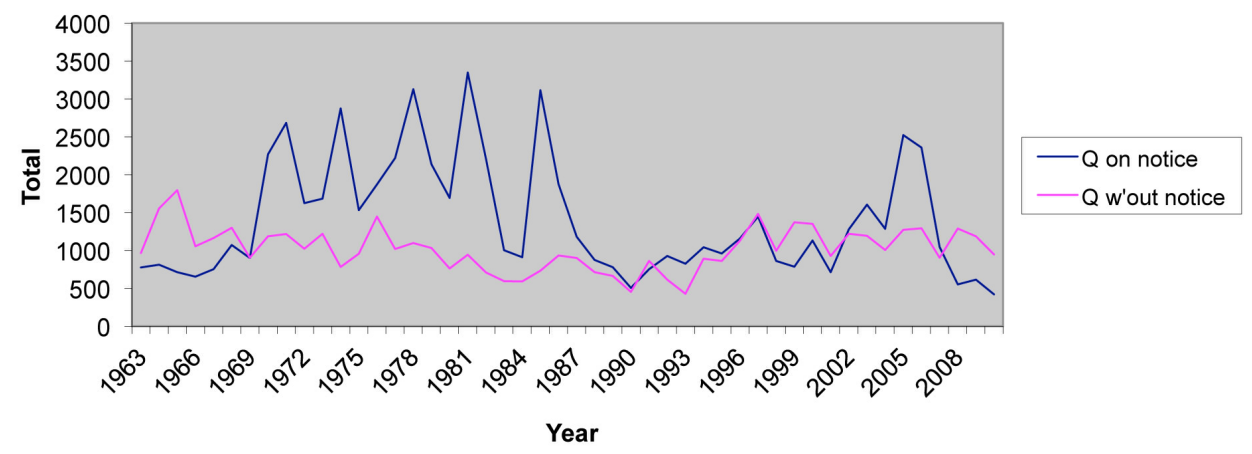

Figure 5.1 Questions to Government, 1963-2010

Source: Annual reports of the House of Representatives and the Senate.

\section{Committees}

If Question Time is the most high-profile means, parliamentary committees are seen as an increasingly important vehicle of ministerial accountability. Parliamentary committees have a number of advantages over Questions On or Without Notice, and they can give a rather broader and fuller account of ministerial performance. First, because they work through inquiries, they can more thoroughly investigate policy and administration in a particular area and the role of the minister therein. Second, in receiving written submissions and holding hearings with stakeholders, a more rounded picture of the role and performance of ministers and their departments can be gained. As accountability revolves around explanation and interrogation of that explanation, the more deliberative committee process allows this more directly. Third, it has been claimed that properly functioning committees develop internal modes of working that overcome the partisan divisions of other areas of parliamentary life. Working in a small, focused group, committees can develop a certain esprit de corps that breaks down party divisions and sees them develop a degree of independence and willingness to defy their party leaderships and dissent from established party positions (Sartori 1982). Moreover, because committees are expected to base their findings on the evidence they receive in the course of their inquiries rather than on the basis of the predetermined positions of their political parties, again they have the potential to provide a more objective, or at least bipartisan, perspective on ministerial performance. And last, where the committees specialise by subject area, they have the capacity to acquire expertise and experience over time and are consequently better placed to 
scrutinise the executive and hold it to account. But these are generic advantages of parliamentary committees and the extent to which committees in the Australian Parliament actually develop them needs closer investigation.

There are three systems of standing committee, specialising by policy area (and allied to specific government departments and agencies)-house, joint and senate - with the Senate dividing the legislative and investigative roles between a system of paired committees. ${ }^{1}$ In addition there are select committees, established by the parent chamber to investigate a specific matter, ceasing to exist when they have reported (though they are rarely used in the House). Whilst all have nominally the same remit - that of investigating the policy, administration, finances and legislation of the ministries within their competency (with the Senate legislative standing committees responsible for scrutinising bills and draft bills, estimates, annual reports and 'performance', and reference committees responsible for investigating other matters; Senate Standing Order 25[2]) - the differences in the way their parent chamber operates have seen an informal division of labour emerge between them. Because committees do not generally have the power to initiate their own inquiries, they are reliant on references from the parent chamber. ${ }^{2}$ With the government by definition holding a majority in the House and party lines largely adhered to, house committees have tended to focus on prospective policy issues, perhaps in cooperation with the minister. Matters potentially embarrassing to the government are unlikely to be investigated. But the government rarely has a majority in the Senate, and therefore cannot block references of bills or matters for investigation to committees for inquiry. Consequently, the bulk of the legislative scrutiny and scrutiny of ministers and departments takes place in the Senate. To illustrate, the House Procedure Committee reported in 2010 that, at the time of writing, 90 per cent of house standing committee inquiries were policy investigations and 10 per cent government scrutiny. By contrast, inquiries by senate committees were approximately 30 per cent for policy and scrutiny combined, with the remaining 60 per cent legislative inquiries (Standing Committee on Procedure 2010, 111-13). ${ }^{3}$ The JCPAA is the main vehicle for budgetary scrutiny, though the senate estimates process is also tied to investigating departmental finances (and in fact ranges rather more widely).

Such is the perceived centrality of the senate committee system to the holding of the ministry to account that when the Howard Government won a rare and narrow senate majority, serious concerns were raised about Parliament's

\footnotetext{
1 The system of paired committees was abolished under the Howard Government's senate majority (ensuring all committees had a government chair) but reinstated under Labor, when the Senate was again under no single-party control.

2 They do have ongoing references to examine annual reports though these are little utilised.

3 In comparison, the proportion for scrutiny in the British House of Commons was approximately 60 per cent.
} 
continued capacity to hold the executive to account in any meaningful way (see, for example, Sawer 2005). Senate committees require a matter to be referred by the Senate as a whole, meaning a government majority in the Senate had the capacity to block all senate scrutiny of bills and government policy. As it turned out, it seemed that the Government accepted the principle that the senate committees should continue to review significant bills and these continued to be referred (albeit with sometimes ridiculously short time frames for reporting). The principle of executive scrutiny was, it seems, less engrained. References to committees were blocked. Evans (2008b) compares the success rate of motions for references to senate committees before and during the period of government senate control.

Table 5.1 Sources of Committee Motions

\begin{tabular}{|c|c|c|c|c|}
\hline Date & $\begin{array}{c}\text { Total } \\
\text { motions }\end{array}$ & $\begin{array}{c}\text { Total } \\
\text { negatived }\end{array}$ & $\begin{array}{c}\text { Non-govt } \\
\text { motions }\end{array}$ & $\begin{array}{c}\text { Non-govt } \\
\text { motions } \\
\text { negatived }\end{array}$ \\
\hline 2001-04 & 63 & 10 & 60 & 10 \\
\hline $1.7 .05-20.9 .07$ & 63 & 38 & 52 & 38 \\
\hline
\end{tabular}

Source: Evans (2008b).

Table 5.1 reiterates the significance of the party political element of executive accountability and the inevitable, adversarial component that that entails. It clearly shows how the Opposition and minor parties were the major source of motions referring matters to committees for consideration. Prior to 2005, with no party controlling a majority in the Senate, most of these motions were approved. Once the Government gained control of the Senate, it vetoed the majority of the potential committee inquiries, including high-profile and controversial 'policy fiascos' such as the Australian Wheat Board's involvement in Iraq; consequently, accountability was reduced.

Sartori (1982) argues that committees overcome established partisan positions by maintaining unanimity - achieved by committee members operating 'give and take' or the principle of 'deferred reciprocal compensation'. Where a committee works on the basis of majority rather than unanimous decision making, it could arguably be said not to be a functioning committee at all (Sartori 1982, 230). The reality is that party lines are largely adhered to in senate committees and investigations rarely proceed unanimously; there are few significant or controversial inquiries that do not result in dissenting reports. Where the Senate is not under government control, the Opposition and perhaps the minor parties will agree to the report, with the government members composing a minority report largely rejecting the criticisms contained in the main one. Under the Government's period of senate control, it was, predictably, the Opposition and 
minor parties that contributed the dissenting report or reports. The contrast with, for instance, the British House of Commons select committees, where unanimity and cross-party agreement in reports are prioritised, is marked.

It would seem then that, in this respect at least, the benefit of committees does not apply in the Senate. Sartori, of course, privileges the deliberative process through which committees work rather than their outputs. An alternative view would be that rather than the single perspective that dominates a unanimous report and the compromises and fudges that maintaining cross-party consensus entail, allowing minority reports enables a wider range of viewpoints to be represented (Mattson and Strøm 1995, 283-4). The difficulty here is that, if the dissenting reports are merely a vehicle for existing party positions then there is no wider range of views represented and it is easier for any criticisms to be dismissed as partisan point-scoring. Moreover, governments are only expected to respond to the main report: where the government controls the Senate, government would escape responding to criticism from other parties' senators.

Given the accountability process conventionally revolves around interrogation of ministers and their explanation, the government response is an important part of the accountability process. Part of the appeal of committees in the accountability process is that they have a deliberative dimension: in the course of an inquiry, government can make a written submission and ministers may appear at hearings (though they cannot be forced to and, with the majority of the ministry in the House, the minister responsible is more likely to be represented by a 'proxy' senate representative). And, following the committee's final report, government should provide a written response to it. Where minority reports exist then any issues raised are unlikely to be addressed, of course. Moreover, the thoroughness of the response is likely to vary and to be contingent on the circumstances of the minister: they are under no obligation to comprehensively address any criticisms and, at times, are likely to find it more politically expedient to ignore them altogether. Whilst the government is expected to provide responses within three months, they are frequently late and at times never materialise at all. The Senate lacks the mechanisms to force a government formed in the House to act so, in the absence of action taken in the House against the government (by definition, by its own backbench), there is little that can be done directly. The only retribution would be through indirect collateral damage from any impact on the government's popularity (and it should be noted that reports from house committees, which are not as hostile to government, also go without responses).

It was the failure of government to respond to committee inquiries that led to accusations that 'democracy' was being 'denied' (Ryle and Pryor 2005); certainly, the Howard Government, at which these accusations were levelled, evidently did not accord any great priority to committee reports or to the 
convention that they be replied to relatively promptly. Attempts to measure the 'effectiveness' of parliamentary committee reports have focused on the report recommendations and their subsequent treatment by government (for example, Hindmoor et al. 2009; Russell and Benton 2011) as one dimension of measuring the strength of Parliament vis-a-vis the executive. But from an accountability perspective, the impact of the committee's recommendations on policy is less important than the evaluation contained in the report and the government's subsequent explanation and justification of its record and future course of action. Yet governments consistently fail to respond to committee reports in a timely fashion (currently the 'agreed' deadline for a response is three months in the House and six in the Senate).

The most recent update of the number of committee reports that have not received a response within the agreed time frame is 133 in the Senate and 61 in the House. There are often legitimate reasons for failing to meet the deadline: the department may be waiting for the outcome of a review or new results of some sort to be made available before responding, for example. Clearly, though, some governments have simply decided not to respond to particular committee reports: the Howard Government left office in 2007 without ever providing a proper response to the Senate Select Committee report on the 'children overboard affair', A Certain Maritime Incident (Select Committee on a Certain Maritime Incident 2002), simply reporting that the 'government response may be considered in due course' (Abetz 2007, 110). On taking office in 2007, the Labor Government committed to responding to committee reports more promptly than its predecessor (Faulkner 2008), yet the total number currently outstanding is higher than at the change of government. (The figures were then 106 for the Senate and 72 for the House).

One aspect of the senate committee process that requires no reference and over which non-government parties have a free hand is senate estimates. The thrice-yearly estimates process (main, supplementary and additional) allows the most sustained scrutiny of the minister (or their senate delegate) and their department. The starting point is the estimates of expenditure to be included in the government's appropriation bills, with the Senate's thematic committees taking responsibility for scrutinising the departments within their remit. Whilst nominally focused on the narrow scrutiny of proposed expenditure, the estimates process has evolved into a very much broader-ranging scrutiny of government policy and administration. Previous governments have been frustrated by this and have attempted to narrow the scope of estimates hearings to focus not on what is being done - the merit of the government's legislative program-but on how it is being done: the efficiency with which it is being implemented. Such attempts have been denied: the appropriation bills are a claim on the public purse and anything that relates to or influences that claim 
is legitimate for the committee to investigate (Evans 2008a, 368): 'as an essential part of [the] appropriations process, the estimates committees evaluate the appropriateness of programs' (Uhr 1989, 6).

Estimates might appear the closest to clear, apolitical accountability that Parliament achieves. It is, after all, focused on the activities and record of the individual minister and their officials rather than the whole of the government and has a clear evidence base in estimates of expenditure, departmental reports, ANAO reports and other official publications. Explicit attempts have been made by governments to steer the estimates process away from a perceived obsession with the inputs and the process and towards the success of specified policy in achieving specified outputs; from the politically contentious issue of policy formulation to how successfully it has achieved its goals (Mulgan 2008).

It is, however, still an essentially political activity. In order to maximise media coverage for each one, no more than four committees will conduct their estimates hearings at the same time, again highlighting the role of the media in the whole process of accountability. Questioning will be conducted almost exclusively by non-government senators and aimed at uncovering evidence of poor administration, flawed assumptions or partisan motives, for instance. Ministers or, in the more frequent instances where the minister is based in the House, their senate spokespersons are questioned directly, but much of the interrogation will be directed at their departmental officials and is generally far more focused on operational details (the decision-making process, the details of policy design and implementation, and so on) than parliamentary questions, for example; it has been speculated that this might have increased over time, as service delivery is shifted out of direct state control (Brenton 2010). Nonetheless, and in keeping with the political nature of parliamentary accountability, even questions directed to officials could be seen as a proxy attack on the minister and their managerial competence.

Even so, either in spite of this political contestation or because of it, or due to the apparent inadequacies of other parliamentary means for holding ministers to account, the public prominence of senate estimates has seemingly continued to rise, as has the priority given to it by the senators themselves. The amount of parliamentary time spent on estimates has grown steadily and the number of column inches in Hansard it generates has grown as well (Mulgan 2008, 62).

Establishing how well committees perform in holding the government to account is difficult (see Larkin 2010). Looking at the formal powers of committees says nothing about how those powers are used. One can count the number of inquiries held, hearings held or reports published, but these only measure activity and not 'effectiveness'; a lack of activity might indicate a lack of effectiveness but the inverse - that activity equals effectiveness - clearly does not hold. The 
number of times a committee caused a change or reversal in government policy would be one measure but, even if one could identify the committee as the sole cause of this, there is also the possibility that government policy may change in anticipation of committee objections. And of course there are no agreed standards: governments might well object that a committee is interfering in the policy process, whilst the committee (or the non-government members of it) complains that the government is ignoring the will of Parliament. But what can be established is the extent to which the government fails to provide information to committees, refuses to appear (or prevents staff from doing so, on which there is more discussion below) or fails to deliver a response to a committee report on time or at all. The lack of commonly held and enforceable minimum standards of government cooperation with the senate committees clearly limits their potential effectiveness. The government, of course, has to remain free to reject committee conclusions or recommendations, but should be obliged to explain itself and its reasons for doing so. Doing so would, again, merely bring Australia's Parliament into line with its counterparts.

\section{Ministerial Staff and the 'Accountability Vacuum"}

A characteristic of Westminster-derived models of administration has been a clear dividing line between the political executive and a 'neutral' bureaucracyneutral insofar as it serves governments of any political persuasion equally. Of course it has long been observed that the bureaucracy has interests of its own that it may try to advance, be they budget-maximising or bureau-shaping or something else entirely, as well as a suspicion by government ministers that the Public Service is predominantly staffed by sympathisers with political parties other than their own. In order to more closely align the interests of the bureaucracy with those of the executive, various measures have been introduced in Australia to increase its 'political responsiveness' (see MacDermott 2008). This has led to fears of bureaucratic politicisation; however, the lines of accountability are still relatively clear and the distinction between departmental and more political work defined in codes of conduct (Special Minister for State 2008).

Around the edges of ministerial accountability, however, is a regiment of special advisors. They are directly employed by ministers and answer directly to them. With special advisor roles having developed in a largely ad-hoc manner and the role of each differing in each ministerial office and each appointment (for example, an advisor taken on secondment from the Public Service may well have a very different role from one drawn from the party), there has been little in the way of regulation of their behaviour or formalising of their lines of accountability; such 
regulation as there is appears in the Members of Parliament (Staff) Act 1984 (the ' $M O P(S) A c t$ ') but is largely directed at ensuring no conflicts of interest exist on entering the minister's office. But what is clear is that special advisors have acquired a substantial policy development role and 'enjoy a level of autonomous executive authority separable from that to which they have customarily been entitled as the immediate agents of the minister' (Select Committee on a Certain Maritime Incident 2002, para 7.107). Yet, unlike ministers or officials, they are largely immune from direct scrutiny by Parliament, and accountable only through their minister. Opinion on whether they are entitled to immunity has been divided; however, the Parliament's inability to put into force its power to compel individuals without immunity from appearing before committees has seemingly rendered this somewhat academic (Select Committee on a Certain Maritime Incident 2002, paras 7.137-43).

Parliament's inability to scrutinise ministerial staff as well as ministers creates the clear potential for an accountability 'vacuum' (Keating 2003). Where ministerial staff are working to the minister's direct instruction, the chain of accountability running through the minister to Parliament may hold. But if they are operating with a degree of delegated authority and autonomy, it breaks down. A minister can claim ignorance of their activities and decline responsibility for the actions of their staff whilst, at the same time, the advisor can escape being held to account by Parliament. Given the established preference for blame avoidance on the part of elected representatives (see Weaver 1986), the potential for ministers to blame staff - safe in the knowledge that there is likely to be little scrutiny of their respective roles - is clear.

Indeed, events such as the 'certain maritime incident' would suggest that this accountability gap is not simply potential or hypothetical but very real, and that it has indeed been used by ministers to dodge accountability. In this instance, the minister claimed information had been passed to his advisors but they had not then informed him. But the veracity of this was never investigated because the minister was able to prevent the advisors appearing before the senate inquiry into the matter. Keating sums up the accountability vacuum thus:

The government is maintaining: first, that key advisers failed to provide critical information to ministers. Second, because ministers were not properly informed, ministers can now avoid taking responsibility for the actions (or lack of action) of their personal advisers, while denying the right of parliament to question those advisers. Furthermore, the government itself has taken no action on its own behalf to bring the relevant advisers to account. (Keating 2003, 92-3)

The Rudd Government introduced a code of conduct for ministerial staff to supplement the $\operatorname{MOP}(S)$ Act in 2008. It includes, amongst other things, clauses 
governing disclosure of gifts, divestment of outside business interests where a potential conflict of interest exists, and the importance of honesty. In the light of the 'children overboard' saga (under the Howard Government), it also includes an obligation to '[fa]cilitate direct and effective communication between their minister's department and their minister' (Special Minister of State 2008). But it makes no provisions for accountability to Parliament, instead limiting advisors' executive role on the basis that if they have no executive role, they need have no direct accountability to Parliament. Moreover, there are no clear sanctions. Any punishment for a breach of the code of conduct will be determined by the prime minister's chief of staff and the relevant minister, leaving the accountability vacuum largely untouched and ensuring the minister's capacity for blame avoidance remains intact (Maiden 2008).

\section{Conclusions}

We have considered some of the means through which parliaments hold ministers to account. In doing so, we have primarily focused on parliament's capacity to extract information from ministers and to compel them to explain their actions. But, as Mulgan emphasises, accountability is not confined to scrutiny and for ministerial accountability to parliament to be properly realised there needs to be some scope for rectification and sanction: ministers need to be held to account as well as being called to account $(2003,9)$.

It is in relation to parliament's capacity to sanction that the implications of King's (1976) observation about the multiple relationships involved in executivelegislative relations become apparent. In the investigative or scrutinising aspects of the accountability process - the extraction of information and explanationthe key relationship is between the executive and the opposition front and backbenches. Ministers will attempt to avoid blame for any disappointments or controversies and to justify their actions and outcomes through contextual explanation. The opposition will be engaged in a process of apportioning blame and attempting to label the minister incompetent (and, by association, calling into question the governing competence of the entire government). The nongovernment parties, however, have no direct capacity to sanction ministers for poor performance. They can investigate ministerial performance and can label the minister a failure by interrogating and casting doubt on explanations for their performance. Instead, the Senate may express its displeasure through passing a censure motion, but that is little more than a public display of disapproval: 'If the Senate chooses to censure a minister...ministers shrug and continue in their post' (Weller 2007, 204). The issue of sanction is a product of relationships within the governing party. 
The ultimate sanction for ministerial failure is removal from post, either to a less prestigious ministerial post or back to the backbenches. The prime minister is responsible for the allocation of ministerial portfolios and so it is the relationship between an individual minister and the prime minister that is pre-eminent in terms of this element of accountability. ${ }^{4}$ The prime minister is in turn dependent on the continued confidence of the parliamentary party or the 'party room' described by Weller as 'the gatekeepers to office and the sentinels protecting and scrutinising cabinet' $(2007,200)$-for continued survival. In this respect, the opposition and minor parties are not without the power of sanction but it is a power that can only be applied indirectly, acting as 'inducer rather than an enforcer' (Mulgan 2003, 62).

In order to 'induce' real rectification or sanction, the non-governing parties must use parliament to attract media and public attention to ministerial shortcomings and generate sufficient public outrage to put sufficient pressure on the governing party to force a minister from office or engineer a policy reversal. Weller (2007, 213) argues that '[a]ccountability to the party is the only immediate means that makes sense under existing practices', dismissing accountability through parliament as 'essentially rhetorical'. For Weller, accountability to the party room is generated through ambition and rivalry and disputes over policy within the party itself. But the reality is that the sanction aspect of ministerial accountability operates 'through' the party room rather than 'to' it. Unless parliament can properly scrutinise ministerial activity by accessing information, by asking questions and receiving proper answers, and by requiring ministers to provide an explanation of their decisions and interrogating those decisions thoroughly, and without the pressure on ministers that this can generate, the pressure on the governing party is lessened and accountability to the party room is weakened. This is why any scope for ministers to evade scrutiny is a cause for concern.

\section{References}

Abetz, E. 2007. Senate Hansard, 21 June. Canberra: Parliament of Australia.

Bovens, M. 2005. 'Public Accountability'. In The Oxford Handbook of Public Management, eds E. Ferlie, L. E. Lynn jr and C. Pollitt. Oxford: Oxford University Press.

4 The prime minister may not be entirely free to appoint who they choose; there may be the 'big beasts' of the party to placate and balance between different wings or factions to maintain (the factions have formalised this within the Labor Party). But the allocation of specific portfolios is the gift of the prime minister and it is the prime minister who ultimately has the power to sanction ministers. 
Brenton, S. 2010. Ministers or Managers: Changing Conceptions of Accountability through Financial Management. Paper presented to the Australasian Political Studies Association Conference, Melbourne, 28 September.

Cowley, P. 2002. Revolts and Rebellions: Parliamentary Voting under Blair. London: Politico's.

Elgie, R. and J. Stapleton. 2006. 'Testing the Decline of Parliament Thesis: Ireland, 1923-2002'. Political Studies 54(3): 465-85.

Evans, H. (ed.). 2008a. Odgers' Australian Senate Practice. Twelfth edition. Canberra: Department of the Senate.

Evans, H. 2008b. The Senate, Accountability and Government Control. Parliamentary Studies Paper no. 4. Canberra: Crawford School of Economics and Government, Australian National University.

Faulkner, J. 2008. Restoring Integrity to Government. Ministerial Statement, 4 December, Parliament House, Canberra, <http://www.senatorjohnfaulkner. com.au/file.php?file $=/$ news/VAYCKHXIYU/index.html $>$

Flinders, M. and A. Kelso. 2011. 'Minding the Gap: Political Analysis, Public Expectations and the Parliamentary Decline Thesis'. British Journal of Politics and International Relations 13(2): 249-68.

Halligan, J., R. Miller and J. Power. 2007. Parliament in the Twenty-First Century: Institutional Reform and Emerging Roles. Melbourne: Melbourne University Press.

Hamer, D. 2004. Can Responsible Government Survive in Australia? Second edition. Canberra: Department of the Senate.

Harris, I. C., B. Wright and P. E. Fowler (eds). 2005. House of Representatives Practice. Fifth edition. Canberra: Department of the House of Representatives.

Hindmoor, A., P. Larkin and A. Kennon. 2009. 'Assessing the Influence of Select Committees in the UK: The Education and Skills Committee, 1997-2005'. Journal of Legislative Studies 15(1): 71-89.

Keating, M. 2003. 'In the Wake of "A Certain Maritime Incident": Ministerial Advisors, Departments and Accountability'. Australian Journal of Public Administration 62(3): 92-7.

King, A. 1976. 'Modes of Executive-Legislative Relations: Great Britain, France, and West Germany'. Legislative Studies Quarterly 1(1): 11-36. 
Larkin, P., 2010, Can Committee Performance Be Measured? Papers on Parliament no. 54. Canberra: Department of the Senate.

MacDermott, K. 2008. Whatever Happened to Frank and Fearless? The Impact of New Public Management on the Australian Public Service. Canberra: ANU E Press.

McGowan, A. 2008. 'Accountability or Inability? To What Extent Does House of Representatives Question Time Deliver Executive Accountability Comparative to Other Parliamentary Chambers? Is There a Need for Reform?' . Australasian Parliamentary Review 23(2): 66-85.

Maiden, S. 2008. 'Staffers' Conduct Code "Sanction Free"'. The Australian, 26 June.

Mattson, I. and K. Strøm. 1995. 'Parliamentary Committees'. In Parliaments and Majority Rule in Western Europe, ed. H. Doring. New York: St Martin's.

Mulgan, R. 2003. Holding Power to Account: Accountability in Modern Democracies. Basingstoke, UK: Palgrave Macmillan.

Mulgan, R. 2008. 'The Accountability Priorities of Australian Parliamentarians'. Australian Journal of Public Administration 67(4): 457-69.

Power Inquiry. 2006. Power to the People, <http://www.powerinquiry.org>

Rasiah, P. 2006. Does Question Time Fulfil its Role of Ensuring Accountability? Discussion Paper 12/06. Canberra: Democratic Audit of Australia. <http:// democratic.audit.anu.edu.au/papers/20060424_rasiah_qt.pdf>

Rhodes, R. A. W. 1996. 'The New Governance: Governing without Government'. Political Studies 19: 652-67.

Russell, M. and M. Benton. 2011. Selective Influence: The Policy Impact of House of Commons Select Committees. London: The Constitution Unit.

Ryle, G. and L. Pryor. 2005. 'Democracy Denied'. Sydney Morning Herald, 20 June.

Sartori, G. 1982. The Theory of Democracy Revisited. Chatham, NJ: Chatham House.

Sawer, M. 2005. The Senate Changeover-Implications for Democracy. Paper. Canberra: Democratic Audit of Australia. <democratic.audit.anu.edu.au/ papers/200507_sawer_senate.pdf>

Select Committee on a Certain Maritime Incident. 2002. A Certain Maritime Incident. Canberra: Senate. 
Special Minister of State. 2008. Code of Conduct for Ministerial Staff. Canberra: Australian Government. <http://www.smos.gov.au/media/code_of_conduct. html>

Standing Committee on Procedure. 2010. Building a Modern Committee System: An Inquiry into the Effectiveness of the House Committee System. Canberra: House of Representatives.

Strøm, K. 2003. 'Parliamentary Democracy and Delegation'. In Delegation and Accountability in Parliamentary Democracies, eds K. Strøm, W. C. Muller and T. Bergman. Oxford: Oxford University Press.

Uhr, J. 1989. Public Expenditure and Parliamentary Accountability: The Debatable Role of Senate Estimates Committees. Papers on Parliament no. 6. Canberra: Department of the Senate.

Weaver, R. K. 1986. 'The Politics of Blame Avoidance'. Journal of Public Policy 6(4): 371-98.

Weller, P. 2007. Cabinet Government in Australia, 1901-2006. Sydney: UNSW Press.

Wheare, K. C. 1963. Legislatures. London: Oxford University Press. 